\title{
Reconocimiento y ejecución de laudos arbitrales anulados en el lugar del arbitraje
}

Fernando Cantuarias S.

De conformidad con la Ley General de Arbitraje (en adelante simplemente LGA), «[... ] cuando la sede del arbitraje esté localizada fuera del Perú (independientemente de cualquier otro factor de conexión como podría ser la nacionalidad o el domicilio de las partes o la materia controvertida), este arbitraje [...] [es] considerado por la LGA como Arbitraje Extranjero». ${ }^{1}$

1 Fernando Cantuarias Salaverry, «Nuevo marco normativo aplicable al Arbitraje en nuestro país: Ley General de Arbitraje -Ley No 26572» en: Scribas, Revista de Derecho, Arequipa, 1996, No 2, p. 252. En el mismo sentido: Artículo 56(2) de la ley española de arbitraje: «Se entiende por laudo arbitral extranjero el que no haya sido pronunciado en España"; Artículo 52० de la nueva ley de arbitraje de Suecia de 1999: "An award made abroad shall be deemed to be a foreign award [... "); Segundo párrafo del Artículo $1422^{\circ} \mathrm{del}$ Código de Comercio Reformado de México de 1993: "Cuando el lugar del arbitraje se encuentre fuera del territorio nacional, conocerá del reconocimiento y de la ejecución del laudo el juez de primera instancia federal [...]»; Artículo $79^{\circ}$ de la Ley de Arbitraje y Conciliación No 1770 de Bolivia de 1997: «Se entenderá por laudo extranjero toda resolución arbitral de fondo que haya sido dictada fuera de Bolivia"; Artículo 1719\%(1) del Código Judicial belga, según modificación de 1998: "The President of the Court of First Instance decides, upon request, on the application for the enforcement of arbitral awards rendered abroad [...]"; Artículo 34(1) de la Ley de Arbitraje del Brasil de 1996: "Considerase sentenca arbitral estrangeira a que tenha sido proferida for a do território nacional»; y, Artículo $198^{\circ}$ del Estatuto de los Mecanismos Alternativos de Solución de Conflictos Decreto $\mathrm{N}^{\circ}$ 1818 de 1998 de Colombia: «Es extranjero todo laudo arbitral que se profiera por un tribunal cuya sede se encuentra fuera del territorio nacional». La misma regla es aplicada por el artículo $1061^{\circ}$ de la German Arbitration Act, el artículo $99^{\circ}$ del Arbitration Act de Inglaterra de 1996, el artículo $44^{\circ}$ de la Arbitration and Conciliation Act de la India de 1995, el artículo $45^{\circ}$ de la Ley de Arbitraje de Guatemala de 1995 , el artículo $40^{\circ}$ de la Ley de Arbitraje, Conciliación y Mediación de Panamá de 1999 y el artículo $839^{\circ}$ del Código Procesal Civil italiano, según reforma de 1994, entre otros. 
Para estos efectos, la LGA cuenta con un capítulo especial referido al reconocimiento y la ejecución de laudos arbitrales extranjeros (Capítulo Octavo de la Sección Segunda de la LGA, artículos $127^{\circ}$ al 131\%).

En ese sentido, el artículo $128^{\circ}$ de la LGA dispone que será «[...] de aplicación al reconocimiento y ejecución de los laudos arbitrales dictados fuera del territorio nacional cualquiera haya sido la fecha de su emisión, pero teniendo presente los plazos prescriptorios previstos en la ley peruana y siempre que se reúnan los requisitos para su aplicación, la Convención Interamericana sobre Arbitraje Comercial Internacional del 30 de enero de 1975 o la Convención sobre Reconocimiento y Ejecución de las Sentencias Arbitrales Extranjeras del 10 de junio de 1958, o cualquier otro tratado sobre reconocimiento y ejecución de laudos arbitrales del cual el Perú sea parte. El tratado a ser aplicado, salvo que las partes hayan acordado otra cosa, será el más favorable a la parte que pida el reconocimiento y ejecución del laudo arbitral, sin perjuicio de lo indicado en el artículo $129^{\circ}$ ".

Existe un número importante de tratados relativos al reconocimiento y a la ejecución de sentencias judiciales y laudos arbitrales extranjeros, de los que el Perú es parte en muchos de ellos. ${ }^{2}$

De todos estos tratados, el más importante es, sin duda alguna, la Convención de Nueva York de 1958. Veamos seguidamente porqué.

\section{La Convención de Nueva York de 1958 y su ámbito de aplicación}

El Convenio sobre Reconocimiento y Ejecución de las Sentencias Arbitrales Extranjeras (más conocido como la Convención de Nueva York de 1958), ha sido ratificado a la fecha por más de ciento treinta estados. ${ }^{3}$

2 El Perú es parte de los siguientes tratados: La Convención de Lima de 1878, la Convención de Montevideo de 1889, la Convención de Caracas de 1911, el Tratado de Derecho Internacional Privado de La Habana de 1928, la Convención de Montevideo de 1940, la Convención de Panamá de 1975, el Convenio Interamericano de Montevideo de 1979 y la Convención de Nueva York de 1958. Sobre el particular, leer a: Alejandro M. Garro, "Armonización y unificación del Derecho privado en América Latina: esfuerzos, tendencias y realidades", en: Themis, Revista de Derecho, Lima, No 24, 1993, p. 13 y ss.

3 Al 03 de diciembre de 2002, ciento treintidós (132) países son parte de esta Convención. A saber: Albania, Alemania, Antigua y Barbuda, Arabia Saudita, Argelia, Argentina, Armenia, Australia, Austria, Azerbaiyán, Bahrein, Bangladesh, Barbados, Bélgica, Benin, Bielorrusia, Bolivia, Bosnia y Herzegovina, Botswana, Brasil, Bulgaria, Burkina 
Los más destacados expertos en la materia consideran este instrumento internacional, como el más importante tratado relativo al arbitraje internacional. ${ }^{4}$

Y no es para menos, ya que este tratado se aplica al reconocimiento y a la ejecución de todos los laudos arbitrales que hayan sido dictados fuera del lugar en donde se pide tal reconocimiento y ejecución, ${ }^{5}$ aun cuando

Faso, Brunei, Camboya, Camerún, Canadá, Colombia, Costa Rica, Costa de Marfil, Croacia, Cuba, Chile, China, Chipre, Dinamarca, Djibouti, Dominica, Ecuador, Egipto, Eslovaquia, Eslovenia, España, Estados Unidos de América, Estonia, El Salvador, Federación Rusa, Filipinas, Finlandia, Francia, Georgia, Ghana, Grecia, Guatemala, Guinea, Haití, Honduras, Hungría, India, Indonesia, Irán, Irlanda, Islandia, Israel, Italia, Jamaica, Japón, Jordania, Kazajstán, Kenya, Kuwait, Kirguistán, Lesotho, Letonia, Líbano, Lituania, Luxemburgo, Macedonia, Madagascar, Malasia, Mali, Malta, Marruecos, Mauritania, Mauricio, México, Mónaco, Mongolia, Mozambique, Nepal, Niger, Nigeria, Noruega, Nueva Zelandia, Omán, Países Bajos, Panamá, Paraguay, Perú, Polonia, Portugal, Reino Unido de Gran Bretaña e Irlanda del Norte, República Árabe Siria, República Centroafricana, República de Corea, República Checa, República Democrática Popular Lao, República Dominicana, República de Moldova, República Unida de Tanzania, Rumania, Saint Vicent y Granada, San Marino, Santa Sede, Senegal, Singapur, Sri Lanka, Sudáfrica, Suecia, Suiza, Tailandia, Trinidad y Tobago, Túnez, Turquía, Ucrania, Uganda, Uruguay, Uzbekistán, Venezuela, Vietnam, Yugoslavia (Serbia y Montenegro), Zambia y Zimbabwe. Fuente: Comisión de las Naciones Unidas para el Derecho Mercantil Internacional (CNUMDI), www.uncitral.org/sp-index.htm. El Perú adhirió a este tratado, mediante Resolución Legislativa No 24810, de 04 de marzo de 1988.

4 Alan Redfern \& Martin Hunter, Law and Practice of International Commercial Arbitration, 2da. Ed., Sweet \& Maxwell, London, 1991, p. 63. "The New York Convention of 1958 is the most important international treaty relating to international commercial arbitration". Richard J. Graving, "How Non-Contracting States to the "Universal" New York Arbitration Convention enjoy Third-Party Benefits but not Third-Party Rightsi en: Journal of International Arbitration, 1997, Vol. 14, No 3, p. 167. "The New York Arbitration Convention of 1958 is mencifully short and for the international commercial community succesfully sweet. Without evident hyperbole Lord Mustill has called it "perhaps the most effective instance of international legislation in the entire history of commercial law». Or as President Stephen Schwebel of the International Court of Justice has put it with greater economy but no less accuracy, "it works». Yet another authority, Professor Thomas Carbonneau, has described it as the "universal charter" of international commercial arbitration. También recomendamos leer a: Fernando Cantuarias Salaverry, «Reconocimiento y ejecución de Laudos Arbitrales Internacionales», en: Themis, Revista de Derecho, No 21, Lima, 1992, pp. 17-24.

5 El Artículo 1.1. de este tratado dispone lo siguiente: «La presente Convención se aplicará al reconocimiento y la ejecución de las sentencias arbitrales dictadas en el territorio de un Estado distinto de aquel en que se pide el reconocimiento y ejecución de dichas sentencias, y que tengan su origen en diferencias entre personas naturales o jurídicas». 
hayan sido emitidos en Estados que no sean miembros, salvo que se haya hecho uso de la reserva de reciprocidad dispuesta en el artículo Io .3 de dicho tratado. ${ }^{6}$

En otras palabras, como explica Berg, ${ }^{7}$ la Convención de Nueva York siempre se aplicará al reconocimiento y a la ejecución de los laudos arbitrales dictados en un país distinto a aquel en el que se pide su reconocimiento y ejecución (criterio territorial), con independencia de cualquier otro criterio o factor de conexión, como puede ser la materia controvertida, la

Laurence Craig, William Park \& Jan Paulsson, International Chamber of Commercial Arbitration, 2da. Ed., ICC Publications, París, 1990, p. 660. Explican los autores que el ámbito de aplicación de la Convención de Nueva York es territorial, ya que lo único que hay que verificar es si el laudo arbitral ha sido dictado en un país distinto de aquel en el que se solicita su reconocimiento y ejecución: "The Convention follows a territorial approach with respect to awards, looking to the locality of the arbitral proceedings, and covering awards rendered in a country other than the country where enforcement is sought. The parties to the dispute need not be nationals of contracting States". Albert Jan van den Berg, "Non-domestic Arbitral Awards under the 1958 New York Convention", en: Arbitration International, 1986, Vol. 2, No 3, p. 198. "[...] the Convention always applies to the recognition and enforcement of an arbitral award made in another State [...]".

6 La primera parte del inciso 3) del Artículo $1^{\circ}$ de la Convención de Nueva York, dispone que todo Estado miembro podrá «[...] a base de reciprocidad, declarar que aplicará la presente Convención al reconocimiento y a la ejecución de las sentencias arbitrales dictadas en el territorio de otro Estado Contratante únicamente».

Esta reserva realizada por aproximadamente dos tercios de los Estados miembros de la Convención, permite limitar sus efectos solo a los laudos arbitrales dictados en algún Estado miembro. Los laudos que sean emitidos en algún Estado que no sea parte de la Convención de Nueva York, serán reconocidos y ejecutados de conformidad con algún otro tratado aplicable o mediante la utilización de las normas domésticas que imperen en cada país. Sin embargo, como bien explica Luis A. Breuer G., "La Convención de Nueva York de 1958 y la Convención de Panamá de 1975", en: www.servilex.com.pe/arbitraje/ paraguay/artlbpy.html, p. 3, «[...] el significado práctico de dicha reserva decrece en proporción inversa al número de Estados adherentes".

7 Richard J. Graving, "How Non-Contracting States to the "Universal" New York Arbitration Convention enjoy Third-Party Benefits but not Third-Party Rights, op. cit., p. 169. El autor cita a Albert van den Berg, que señala lo siguiente: "The title of the Convention refers to the "recognition and enforcement of foreign arbitral award".. What is understood by a foreign award can be found in Article 1(1): an arbitral award made in the territory of a State other than the State where the recognition and enforcement of such award is sought. As no other condition is required, the scope of the Convention is very broad: an award made in any foreign country, whether in a Contracting State or not, falls under the New York Convention. Such a definition of the field of application can be said to be the modern tendency in international conventions [...] Under this principle of universality, awards made in Contracting and non- 
nacionalidad o el domicilio de las partes, entre otros, ${ }^{8}$ salvo que los Estados miembros opten por acceder a dicho tratado planteando la reserva de reciprocidad,? temperamento que es compartido por la casi totalidad de expertos ${ }^{10} \mathrm{y}$ fallos jurisprudenciales. ${ }^{11}$

Contracting States are treated alike». Leer además a: Albert Jan van den Berg, "When is an Arbitral Award Non-domestic under the New York Convention of 1958?", en: Pace Law Review, Vol. 6, No 1, 1985, pp. 32-44; y, Albert Jan van den Berg, «Non-domestic Arbitral Awards under the 1958 New York Convention", op. cit., pp. 194-202.

8 Gonzalo García Calderón Moreyra, «El Arbitraje Internacional en la Legislación Peruana», en: Revista Peruana de Derecho Internacional, Tomo XLVI, No 108, Lima, 1996, pp. 196-197. «[...] la aplicabilidad de la Convención de 1958, está subordinada al cumplimiento de dos requisitos: el primero, que exista una sentencia arbitral; y, el segundo, que haya sido dictada en el extranjero, vale decir, que se trate de una sentencia arbitral dictada en el territorio de un Estado distinto de aquel en el que se pide el reconocimiento y la ejecución de dichas sentencias, según la terminología utilizada por la Convención.

$\mathrm{Si}$, como hemos dicho, la aplicabilidad de la Convención depende de los requisitos antes señalados, y no de otras condiciones, la cuestión relativa a la nacionalidad de las partes no reviste importancia en cuanto al reconocimiento y ejecución de sentencias arbitrales dictadas en el extranjero. Ella no podría ser invocada ni aún en el caso de que su derecho interno les prohibiese renunciar a su propia jurisdicción para someterse a un arbitraje extranjero. Cabe citar, en este sentido, la resolución de la Corte Suprema de Italia de 13 de diciembre de 1971, en la que sostiene que la Convención de 1958 deroga la disposición del derecho interno». Ulises Montoya Alberti, «La Convención de Nueva York de 1958 sobre Reconocimiento y Ejecución de Sentencias Arbitrales Extranjeras», en: Revista del Foro No 1 , Colegio de Abogados de Lima, Lima, 1989, p. 185. «El campo de aplicación del Convenio no depende de la nacionalidad de las partes [...]".

9 Al 03 de diciembre de 2002, los siguientes Estados han apelado a la reserva de reciprocidad: Alemania, Antigua y Barbuda, Arabia Saudita, Argelia, Argentina, Armenia, Bahrain, Barbados, Bélgica, Bielorrusia, Bosnia y Herzegovina, Botswana, Brunei, Bulgaria, Croacia, Cuba, China, Chipre, Dinamarca, Ecuador, Eslovenia, Estados Unidos de América, Federación Rusa, Filipinas, Francia, Grecia, Guatemala, Hungría, India, Indonesia, Irlanda, Japón, Jamaica, Kenia, Kuwait, Líbano, Lituania, Luxemburgo, Macedonia, Madagascar, Malasia, Malta, Marruecos, Mauricio, Mónaco, Mongolia, Mozambique, Nepal, Nigeria, Noruega, Nueva Zelanda, Países Bajos, Polonia, Portugal, Reino Unido de Gran Bretaña e Irlanda del Norte, República de Corea, República Centroafricana, República de Moldova, República Unida de Tanzania, Rumania, Saint Vicent y las Granadinas, Santa Sede, Singapur, Trinidad y Tobago, Túnez, Turquía, Ucrania, Uganda, Venezuela, Viet Nam y Yugoslavia (Servia y Montenegro). Fuente: Comisión de las Naciones Unidas para el Derecho Mercantil Internacional (CNUMDI), www.uncitral.org/sp-index.htm. El Perú se ha adherido a este tratado sin apelar a esta reserva.

10 Edward R. Leahy \& Diane F. Orentlicher, "Enforcement of Arbitral Awards issued by the Additional Facility of the International Centre of Settlement of Investment Disputes (ICSID)", en: Journal of International Arbitration, Vol. 2, № 3, 1985, pp. 19-20. 


\section{Tratándose del Perú que se ha adherido a la Convención de Nueva} York sin hacer uso de la reserva de reciprocidad, ${ }^{12}$ estamos obligados a aplicar dicho tratado al reconocimiento y la ejecución de todos los laudos

Estos autores llegan a la misma conclusion, al afirmar que: "[...] the preliminary draft of the New York Convention provided for enforcement of only those awards rendered in a country other than the one in which enforcement was sought. Once the non-territorial basis for enforcement was conceived, the drafting Conference explicitly rejected a proposal by several countries to allow States to refuse to enforce awards that are rendered abroad, but are nonetheless considered "domestic" under the law of the State in which enforcement is sought. It chose instead to adopt a text that allowed countries to enforce awards that are considered "non domestic" even though they are rendered in the enforcing State, but which did not allow countries to refuse to enforce awards rendered abroad on the ground that such awards were considered "domestic" under the law of the enforcing State. Consistent with this decision, the Conference rejected several proposed reservations that would have excluded enforcement of awards rendered abroad but considered "domestic" under the laws of certain countries. Thus, the scope of the territorial basis for enforcement set forth in the Convention could not be narrowed by an enforcing State's law defining what awards are considered "not domestic", and no reservation to this effect could be entered".

$11 \mathrm{La}$ India es el único Estado, hasta donde tenemos conocimiento, que ha interpretado el ámbito de aplicación de la Convención de Nueva York de manera distinta a los demás Estados miembros. Según su Corte Suprema, aun cuando un laudo sea dictado fuera de la India, si el convenio arbitral está sujeto a la legislación hindú, entonces no será de aplicación la Convención de Nueva York. Sobre este tema, V.S. Deshpande, "Foreign Award" in the 1958 New York Convention" y en: International Arbitration, 1992, Vol. 9, No 4, p. 53, señala que: "As the Supreme Court of India has stated: "An award is foreign not merely because it is made in the territory of a foreign State, but because it is made in such a territory on an arbitration agreement not governed by the laws of India. An award made on an arbitration agreement governed by the laws of India, though rendered outside India, is attracted by the saving clause in Section 9 of the Foreign Awards Act and is therefore not treated in India as a foreign awardmm. Obviamente esta postura ha sido activamente atacada. Así, por ejemplo, Jan Paulsson, "The New York Convention's Misadventures in India", en: Mealey's International Arbitration Report, 1992, Vol. 7, No 6, opina de la siguiente manera: "[This is an] example [...] of parochial overreaching by a national legalsystem. It is hoped that the trend will be reversed in India, and not copied elsewhere. For now, India stands alone in this respect; no other legal system has adopted such an aggressively nationalistic posture [...]. It is to be hoped that the Indian legal system will find a way to reverse this deleterious holding and to reassure the international legal community of its intent to apply the New York Convention faithfully». Recientemente esta postura incorrecta del poder judicial hindú, al parecer ha sido superada en su reciente Arbitration and Conciliation Act de 1995.

12 Ulises Montoya Alberti, «Arbitraje Internacional en materia Comercial», en: Diario Oficial «El Peruano», 17 de setiembre de 1993, p. B-15. «El Perú, al ratificar dicha convención, no hizo uso de esta reserva [de reciprocidad], por lo que un laudo de cualquier país, aunque no sea miembro de la Convención de Nueva York, puede presentarse para su ejecución en los tribunales del Perú». 
arbitrales que se dicten en cualquier parte del mundo (obviamente con exclusión del Perú), ${ }^{13}$ debiéndose seguir para el efecto, el estandard utilizado por la Corte de Apelaciones de Nápoli (1978), en los seguidos por G. A. Pap-KG Holzgrosshandlung contra Ditta Giovanni G. Pecoraro. ${ }^{14}$

\section{Las causales contenidas en el artículo V(1)(e) de la Convención de Nueva York}

El artículo V de la Convención de Nueva York establece de manera taxativa siete supuestos en los que no procede reconocer y ejecutar un fallo arbitral dictado fuera del lugar donde se pretende tal reconocimiento y ejecución.

Uno de esos supuestos está contenido en el artículo V(1)(e) del mencionado convenio que establece que procede denegar el reconocimiento de un laudo arbitral extranjero si la parte interesada alega y prueba, que «[...] la sentencia no es aún obligatoria para las partes o ha sido anulada o suspendida por una autoridad competente del país en que, o conforme a cuya ley, ha sido dictada esa sentencian.

Como bien explica Montoya, ${ }^{15}$ esta norma establece dos causales de denegación: «[...] que la sentencia no es aún obligatoria para las partes, $y$

13 El único caso en que este autor entiende que no será de aplicación la Convención de Nueva York a un laudo arbitral dictado fuera de nuestras fronteras, está referido a cuando el convenio arbitral no ha sido celebrado "por escrito". Ello de conformidad con lo dispuesto en los artículos II (1) y IV(1) de dicho tratado. En ese sentido, Ikko Yoshida, "Lessons from The Atlantic Emperor: Some Influence from the Van Uden Case», en: Arbitration International, Vol. 15, No 4, 1999, p. 377, explica que: «As far as the enforceability of awards is concerned, the existence of an arbitration agreement in writing is a necessary precondition".

14 En este caso, la empresa italiana (Ditta Giovanni G. Pecoraro) se opuso al reconocimiento y a la ejecución de un laudo arbitral dictado en Viena en favor de la empresa austríaca G.A. Pap-KG Holzgrosshandlung, argumentando la no aplicación de la Convención de Nueva York, por cuanto Austria (lugar del arbitraje), no era miembro de dicho tratado. Sin embargo, la corte afirmó que: «Austria ratified the New York Convention on May 2, 1961. Even when this would have not been the case, Italy, when adhering to the Convention, had not made any reservation and, in particular, not the reservation of reciprocity. Accordingly, the Convention applies to awards made in Contracting States as well as to awards made in States which did not adhere to the Convention", en: The Yearbook on Commercial Arbitration, 1981, Vol. VI, pp. 228-229.

15 Ulises Montoya Alberti, La Convención de Nueva York de 1958 sobre reconocimiento y ejecución de sentencias arbitrales extranjeras, op. cit., p. 196. 
que la sentencia ha sido anulada o suspendida por una autoridad competente del país en que o conforme a cuya ley haya sido dictada esa sentencia". Analicemos en consecuencia cada supuesto por separado.

\subsection{El laudo no es aún obligatorio entre las partes}

Si revisamos los tratados latinoamericanos aplicables al reconocimiento y a la ejecución de sentencias judiciales y laudos arbitrales extranjeros de los que el Perú es parte, ${ }^{16}$ verificaremos que todos exigen como requisito que se pruebe que el laudo es final o, lo que es lo mismo, que tenga la calidad de ejecutoriado con arreglo a la ley del lugar donde se expidió. ${ }^{17}$

El problema con el requisito de probar «firmeza» o «ejecutoridad», es que en la práctica ello obliga a que el vencedor de un laudo arbitral tenga que solicitar el reconocimiento del laudo ante el poder judicial del lugar donde se llevó a cabo el arbitraje, como requisito ineludible para intentar luego su ejecución en un tercer Estado, ya que es la mejor forma de demostrar que el laudo es firme o final.

Desgraciadamente este trámite que se denomina "doble exequatum, ${ }^{18}$ hace que el reconocimiento y la ejecución de un laudo arbitral extranjero sea un proceso lento, costoso y de incierto resultado. ${ }^{19}$

\section{Ver supra cita No 2.}

17 Artículo $42^{\circ}(3)$ de la Convención de Lima de 1888: «Si la sentencia o resolución estuviese ejecutoriada con arreglo a la ley del país donde se haya expedidon. Artículo $5^{\circ}(\mathrm{b})$ de las convenciones de Montevideo de 1899 y de Caracas de 1911: "Que tenga el carácter de ejecutoriado o pasado en autoridad de cosa juzgada, en el Estado en que se ha expedidom. Artículo 5०(b) de la Convención de Montevideo de 1940: "Que tengan el carácter de ejecutoriados o pasados en autoridad de cosa juzgada en el Estado en donde hayan sido pronunciados". Artículo 2(g) de la Convención de Montevideo de 1979: “Que tengan el carácter de ejecutoriados o, en su caso, fuerza de cosa juzgada en el Estado en que fueron dictados".

18 En la gran mayoría de los casos en los que se arbitran controversias referidas a contratos comerciales internacionales, las partes no tienen interés alguno en ejecutar el laudo en el lugar del arbitraje, ya que generalmente eligen dicho lugar por su neutralidad. Por esta razón, exigirles que ejecuten el laudo ante los tribunales del lugar del arbitraje, es hacerles perder tiempo y dinero. Sobre el tema leer a: Ulises Montoya Alberti, «La Convención de Nueva York de 1958 sobre reconocimiento y ejecución de sentencias arbitrales extranjeras", op. cit., p. 196; y, Jan Paulsson, "Arbitration Unbound: Award detached from the Law of its origin", en: The International and Comparative Law Quarterly, Vol. 30 , 1981 , p. 373.

19 Ramona Martinez, "Recognition and Enforcement of International Arbitration Awards under the NU Convention of 1958", en: International Law, Vol. 24, 1990, p. 495. "The 
En razón de los inconvenientes suscitados con la exigencia de que se pruebe la firmeza de los laudos, la Convención de Nueva York exige simplemente que el laudo sea "obligatorio para las partes". ${ }^{20}$

El problema, sin embargo, es el de precisar qué debe entenderse por «obligatorio para las partes».

Sobre este particular, Berg ${ }^{21}$ informa que la actitud de las cortes de justicia ha sido, por un lado, la de investigar si de conformidad con la ley del lugar del arbitraje el laudo es «obligatorio» (no lo será, por ejemplo, si debe cumplirse con algún requisito formal, como puede ser el depósito del laudo ante el poder judicial, o cuando, de acuerdo con dicha ley local, proceda necesariamente algún recurso); y, por otro lado, la de aplicar un criterio autónomo, "[...] es decir, independiente de la ley que sería aplicable, planteándose que la sentencia se convertiría en obligatoria... en el momento que ésta no sea susceptible de un recurso ordinario basado en sus méritos ante una segunda instancia judicial o arbitraln. ${ }^{22}$

usual commercial treaty language is "final and enforceable». Either "final" or "enforceable" can cause interpretation problems. "Final" implies completion of all permitted appeals. "Enforceable" means some kind of court action, because arbitral awards are not self-executing".

20 Albert Jan van den Berg, "New York Convention of 1958: Consolidated Commentary, Cases reported in Volumes XIII(1988)-XIV(1989)", en: The Yearbook on Commercial Arbitration, Vol. XIV, 1989, p. 592. "The drafters of the New York Convention, considering this system as too cumbersome, abolished it by providing the word 'binding' instead of the word "final"». W. Michael Tupman, "Staying Enforcement of Arbitral Awards under the New York Convention", en: Arbitration International, 1987, Vol. 3, No. 3, pp. 211-212. "It is well established that the drafters of the Convention deliberately substituted "binding" for the term "final" used in the predecessor Convention for the Execution of Foreign Arbitral Awards ("Geneva Convention'). The intent was to eliminate the so-called "double-exequatur"-the requirement, for all practical purposes, that a party must first seek leave to enforce the award in the country of origin in order to prove to a court in another country that the award was "final". This requirement not only imposed an undue burden on the party seeking to enforce an award, but also worked the absurd result of an enforcement proceeding in a country where the other party might not even have assets or where the prospects for successful enforcement were otherwise in doubt. In using the term "binding" instead of final the New York Convention permits enforcement once an award in rendered even though it might potentially, or in fact, be subject to judicial recoursen.

21 Albert Jan van den Berg, "New York Convention of 1958: Consolidated Commentary, Cases reported in Volumes XIII(1988)-XIV(1989)», op. cit., p. 592.

22 Ulises Montoya Alberti, «La Convención de Nueva York de 1958 sobre Reconocimiento y Ejecución de Sentencias Arbitrales Extranjeras", op. cit., p. 196. Gary B. Born, International Commercial Arbitration in the United States, Kluwer Law and Taxation Publishers, Deventon \& Boston, 1994, p. 494. "Some commentators have concluded that 
Nosotros consideramos que debe aplicarse el criterio autónomo, ${ }^{23}$ por lo que la parte que alegue esta causal tendrá que demostrar, de manera fehaciente, que contra el laudo arbitral procede algún recurso sobre el fondo ante otra instancia judicial o arbitral. ${ }^{24}$ De lo contrario, esta causal será inaplicable.

only the availability of judicial review on the merits in its country of forigin prevents an award from being binding". Este fue justamente el temperamento de la Corte Suprema de Suecia, en el caso seguido entre $A B$ Gotaverken vs General National Maritime Transport Co., en el que se señaló que la posibilidad de recurrir en recurso de anulación no significa que el laudo arbitral no sea obligatorio entre las partes, ya que aquí solo interesa analizar si el fondo de la controversia puede ser objeto de apelación: "The possibility of an action for setting aside the award shall not mean that the award is not considered as not being binding [...] $A$ case in which a foreign award is not binding is when its merits are open to appeal to a higher jurisdiction". Idéntica posición asumió una corte de Amsterdam, en el caso seguido por Southern Pacific Properties (Middle East), Limited v. The Arab Republic of Egytp (1984). Sobre el tema leer a: Michael Tupman, "Staying Enforcement of Arbitral Awards under the New York Convention", op. cit., pp. 212 y ss.

23 Albert Jan van den Berg, "New York Convention of 1958: Consolidated Commentary, Cases reported in Volumes XIII(1988)-XIV(1989)", op. cit., p. 592. "An argument in support of the autonomous interpretation is that if the applicable law provides that an award becomes binding only after a leave of enforcement is granted by the court, the "double-exequatur" is in fact reintroduced into the Convention, thus defeating the Convention's drafters attempt to abolish this requirement. Further, the autonomous interpretation has the advantage that it dispenses with compliance with local requirements imposed on awards, such as deposit with a court or even a leave for enforcement from the court of origin, which requirements are for enforcement abroad unnecessary and cumbersome".

24 William L. Craig, "Uses and Abuses of Appeal from Awards", en: Arbitration International, Vol. 4, No 3, 1988, p. 187. "[...] an enforceable award does not have to be final in some absolute sense. It need only have obligatory force between the parties under the local procedural law where it was rendered. In most cases, an award can be deemed binding and enforceable under the Convention as soon as it is rendered. Those cases where it would not be binding would include specific cases where the law of the home jurisdiction permits appeal on the merits or the rules of the arbitral institution permits review within the institution".

Así, por ejemplo, en Fertilizer Corporation of India v. IDI Management Inc. (517 F. Supp. 948 (1981), el perdedor había iniciado el procedimiento de anulación del laudo arbitral en el lugar del arbitraje (en este caso en la India). Sin embargo, la corte norteamericana consideró sin lugar esta causal, por cuanto: "We note the comment of Professor Gerald Asken, General Counsel of the American Arbitration Association: The award will be considered 'binding' for the purposes of the Convention if no further recourse may be had to another arbitral tribunal (that is, an appeals tribunal). The fact that recourse may be had to a court of law does not prevent the award from being "binding". This provision should make it more difficult for an obstructive loser to postpone or prevent enforcement by bringing, or threatening to bring, proceedings to have an award set aside or suspended》. 


\subsection{El laudo ha sido anulado o suspendido por una autoridad compe- tente del país en que o conforme a cuya ley ha sido dictado ${ }^{25}$}

Como explica Montoya ${ }^{26}$ la causal bajo estudio «[...] se aplica solo si la sentencia ha sido efectivamente anulada en el país de origen, ya que en el supuesto que una parte haya simplemente efectuado una petición de anulación solo puede producir la posibilidad de aplazamiento de la decisión sobre la ejecución de la sentencia que señala el artículo VI, pero no la denegación". ${ }^{27}$

Además, esta causal solo resulta aplicable si la autoridad competente identificada en la norma, de manera expresa suspende los efectos del laudo arbitral, no bastando, por tanto, la mera aplicación de la ley arbitral local que así lo disponga. ${ }^{28}$

25 Conforme a la Convención de Nueva York, solo la autoridad competente del país en que, o conforme a cuya ley se dictó el laudo arbitral, puede anularlo, mientras que el poder judicial de los demás paises solo pueden dejar de reconocerlo. Gary B. Born, "International Commercial Arbitration in the United States", op. cit., p. 642. El autor cita varios fallos de tribunales de justicia que confirman esta afirmación: "S.A. Mines, Minerais et Metaux v. Mechema, Ltd., [...] (Brussels Court of Appeal Oct. 14, 1980); Maatschappij voor Industriele Research en Ontwikkeling BVv. Henri Lieuremont and M. Cominassi [...] (French Supreme Court May 25, 1983) [...] Cominco France v. Soguiber SL [...] (Spanish Supreme Court March 24, 1982); Laconian Maritime Enterprises Ltd. v. Agromai Lineas Ltd., [...] (South African Supreme Court August 27, 1985)".

26 Ulises Montoya Alberti, «La Convención de Nueva York de 1958 sobre Reconocimiento y Ejecución de Sentencias Arbitrales Extranjeras", op. cit., p. 196.

27 Pieter Sanders, "A Twenty Years Review of the Convention on the Recognition and Enforcement of Foreign Arbitral Awards», en: The International Lawyer, Vol. 13, No 2, 1979, p. 273. "Under the New York Convention, it is no longer enough to commence an action. The Convention requires proof that the award has been set aside in the country where it was made before enforcement may be refused".

28 Como es el caso, por ejemplo de la LGA peruana. En ese sentido, Albert Jan van den Berg, "New York Convention of 1958: Consolidated Commentary, Cases reported in Volumes XIII(1988)-XIV(1989)", op. cit., p. 597, explica que: "Art. V(1)(e) provides that the award has been [...] suspended by a competent authority of the country in which [...] that award was made. Automatic suspension by operation of law in the country where the award was made -as happens in France-does not fall under the wording of Art. V(1)(e). Furthermore, if an automatic suspension by operation of law in the country of origin were sufficient for "has been suspended" as provided in Art. $V(1)(e)$, it would defeat the system of the Convention. It would mean that by a mere application for setting aside in the country of origin, enforcement would have to be refused under the Convention in other Contracting States. This would run counter to the reasons behind the term "binding" in Art. V(1)(e) and the adjournment provisions in Art. VI". 
De esta manera, resulta bastante remoto que proceda esta causal, porque como hemos indicado, no basta alegar que se puede recurrir o ya se ha acudido a la autoridad competente del país en que o conforme a cuya ley se dictó el laudo arbitral, ${ }^{29}$ sino que además debe probarse que el laudo ya ha sido anulado o suspendido. ${ }^{30}$

29 La autoridad competente del país conforme a cuya ley se dictó el laudo arbitral, es aquella bajo cuyas normas arbitrales se emitió el laudo. Philip J. Mc Connaughay, «The risks and virtues of Lawlessness: $A$ "Second Look» at International Commercial Arbitration", en: Northwestern University Law Review, Vol. 93, № 2, 1999, p. 518. "The interpretative difficult with the reading of Article $V(1)(e)$ [...] arises from the word "law" in the phrase, "the country in which, or under the law of which, [the] award was madn. The courts and commentators to consider the issue uniformly have concluded that Iaw' in Article $V(1)(e)$ refers to the procedural law governing the conduct of the arbitration, not to the substantive law governing the claims that were resolved in the arbitration".

En ese sentido, la posibilidad de que existan dos autoridades competentes (la del lugar del arbitraje y la de la ley arbitral aplicable), se presentará solo en aquellos contados casos en los que las partes acuerden, por ejemplo, arbitrar en Suiza bajo las normas arbitrales de Francia, posibilidad permitida, hasta donde tenemos conocimiento, solo por las leyes arbitrales de estos dos países.

Por ello, el caso International Standard Electric Corporation (ISEC) v. Bridas Sociedad Anonima Petrolera Industrial y Comercial (BRIDAS)(United States District Court S.D. New York) resuelto en 1990, es digno de destacar: Las partes suscribieron un contrato conteniendo una cláusula arbitral, mediante la cual se obligaban a arbitrar según el Reglamento de Arbitraje de la Cámara de Comercio Internacional (CCI). La ley aplicable al fondo de la controversia era la de Nueva York. Como no se había pactado el lugar del arbitraje, la CCI designó a la ciudad de México. Dictado el laudo arbitral en su contra, ISEC inició un proceso ante el poder judicial norteamericano, solicitando que declarara nulo el laudo arbitral, bajo el entendido que al ser la ley de Nueva York la ley aplicable, de conformidad con la Convención de Nueva York le correspondía intervenir. Sin embargo, la corte indicó correctamente, lo siguiente: "The "competent authority" as mentioned in Article V(1)(e) for entertaining the action of setting aside the award is virtually always the court of the country in which the award was made. The phrase "or under the law of which" the award was made refers to the theoretical case that on the basis of an agreement of the parties the award is governed by an arbitration law which is different from the arbitration law of the country in which the award was made.

[...].

Accordingly, we hold that the contested language in Article $V(1)(e)$ of the Convention, the competent authority of the country under the law of which. [the] award was made' refers exclusively to procedural and not substantive law, and more precisely to the regimen or scheme of arbitral procedural law under which the arbitration was conducted, and not the substantive law of contract which was applied in the case". Como que el laudo había sido dictado en México (lugar del arbitraje), bajo la ley procesal arbitral mexicana, en base a la Convención 
Cuando ello no sea así, la única opción, como analizaremos enseguida, será apelar al artículo VI de la Convención de Nueva York.

En efecto, el artículo VI de la Convención de Nueva York dispone que si se "[...] ha pedido a la autoridad competente [...] la anulación o la suspensión de la sentencia [arbitral], la autoridad ante la cual se invoca dicha sentencia podrá, si lo considera procedente, aplazar la decisión sobre la ejecución de la sentencia y, a instancia de la parte que pida la ejecución, podrá ordenar a la otra parte que dé garantías apropiadas".

Esta disposición confirma nuestra afirmación, en el sentido que la segunda causal contenida en el artículo V(1)(e) de la Convención de Nueva York, solo es aplicable si el laudo ha sido anulado o suspendido por la autoridad competente; ${ }^{31}$ ya que si simplemente está en trámite la solicitud, el poder judicial que conoce de un pedido de reconocimiento de un laudo extranjero puede reconocer y ejecutar el laudo arbitral, salvo cuando considere pertinente o prudente, suspender el trámite hasta que recaiga sentencia definitiva en el lugar de origen. ${ }^{32}$

Sobre este particular, Tupman ${ }^{33}$ informa que hasta 1987 se habían reportado cinco fallos judiciales, en los que se hizo referencia al Artículo VI de la Convención de Nueva York, habiéndose denegado la suspensión en tres de ellos ${ }^{34} y$ otorgado en los otros dos. ${ }^{35}$

de Nueva York solo el poder judicial de México podía anular el laudo arbitral, razón por la cual se desestimó el pedido de ISEC.

30 Es más, aún cuando se haya anulado el laudo, en algunos Estados es posible ejecutar el laudo arbitral, como veremos más adelante.

31 Pieter Sanders, «Exposición en la Clausura del Seminario de Arbitraje Comercial Internacional", en: El Arbitraje Comercial en Iberoamérica, Instituto de Cooperación Iberoamericana y el Consejo Superior de las Cámaras Oficiales de Comercio, Industria y Navegación de España, Madrid, 1982, p. 380. «El cumplimiento solamente se rechazará cuando la sentencia "haya sido invalidada", es decir, después de haber sido llevado un procedimiento de invalidación con éxito en el país nativo».

32 Albert Jan van den Berg, "New York Convention of 1958: Consolidated Commentary, Cases reported in Volumes XIII(1988)-XIV(1989)", op. cit., p. 605. "The words "may adjourn" and "if it considers it proper» indicate that the court has discretionary power to adjourn its decision on enforcement of the award and to order the respondent to provide security, pending the setting aside or suspension proceedings in the country of origin".

33 Michael Tupman, «Staying Enforcement of Arbitral Awards under the New York Convention", op. cit., pp. 212 y ss.

34 Los casos son los siguientes: a) Compagnie de Saint-Gobain vs Fertilizer Corporation of India, Ltd. (Tribunal de Grande Instance de Paris, 1970); b) $A B$ Gotaverken vs General National Maritime Transport Co. (Corte Suprema de Suecia, 
En el primero de los casos reportados en el que se denegó el ejercicio de la prerrogativa de suspensión, la corte consideró que solo era aplicable esta facultad cuando la anulación o suspensión se encontrara en trámite ante la autoridad competente del país de origen y no cuando simplemente se estuviera en término para interponer el recurso. ${ }^{36}$

En los otros dos casos denegados, tanto la Corte Suprema de Suecia, ${ }^{37}$ como la Corte de Primera Instancia de Amsterdam, ${ }^{38}$ consideraron que

1979); c) Southern Pacific Properties Ltd. vs República de Egipto (Corte de Primera Instancia de Amsterdam, 1984).

35 Los dos casos son los siguientes: a) Fertilizer Corporation of India vs IDI Management Inc (Corte de Primera Instancia Federal de los Estados Unidos de América, 1981); b) Société Norsolor vs Société Pabalk Tikaret Ltd. Sirketi (Corte de Apelaciones de París, 1981).

36 Compagnie de Saint-Gobain vs Fertilizer Corporation of India, Ltd. (Tribunal de Grande Instance de Paris, 1970). El laudo arbitral se dictó en Nueva Delhi a favor de la empresa hindú. Cuando esta última intentó la ejecución del laudo en Francia al amparo de la Convención de Nueva York, la perdedora se opuso aduciendo, entre otros, que todavía se podía recurrir ante el poder judicial del lugar del arbitraje. Sin embargo, como bien señala Michael Tupman, "Staying Enforcement of Arbitral Awards under the New York Convention" op. cit., p. 212, "[a]rticle VI of the New York Convention might be applicable only if such an application were already pending. The French court accordingly held that a stay was not "an appropriate step" ".

37 AB Gotaverken vs General National Maritime Transport Co. (Corte Suprema de Suecia, 1979). El laudo se dictó en París en contra de una empresa libia, luego de lo cual la perdedora solicitó su nulidad ante el poder judicial francés. Sin embargo, la Corte Suprema de Suecia no amparó esta pretensión. Michael Tupman, "Staying Enforcement of Arbitral Awards under the New York Convention", op. cit., p. 213. "The Supreme Court of Sweden [...] refused to stay enforcement of a foreign arbitral award despite a parallel French court proceeding challenging its validity [...]

The Swedish Supreme Court [established that] [... the possibility of an action setting aside the award shall not mean that the award is not considered as not being binding (...) The choice of the term binding [in the New York Convention] was provided for the party relying on the award. The intent was, inter alia, to avoid the necessity of a double exequatur, or the need for the party relying on the award to prove that the award is enforceable according to the authorities of the country in which it was rendered".

38 Southern Pacific Properties Ltd. vs República de Egipto (Corte de Primera Instancia de Amsterdam, 1984). El laudo fue dictado en París a favor de una empresa de Hong Kong, ante lo cual el gobierno egipcio solicitó su nulidad ante el poder judicial francés. Sin embargo, como bien indica Michael Tupman, «Staying Enforcement of Arbitral Awards under the New York Convention", op. cit., pp. 214-215, la corte no amparó la suspensión del procedimiento de reconocimiento y ejecución del laudo, por cuanto: "[...] the award was binding because it was not "open to appeal on the merits" before a judge or an appeal arbitral tribunal. [T] he mere initiation of an action for setting aside [...] does not have as its 
en aplicación del Artículo VI de la Convención de Nueva York, la suspensión debía ser expresamente ordenada por la autoridad competente del país de origen, no bastando la simple disposición legal en tal sentido. ${ }^{39}$

Por su parte, en los dos casos reportados en los que se decidió suspender el proceso de reconocimiento, las cortes de los Estados Unidos de América y de Francia, ${ }^{40}$ hicieron expresa mención de su facultad discrecional para hacer uso del Artículo VI de la Convención de Nueva York, cuando el laudo se encontrara en trámite de anulación ante la autoridad competente del país de origen. ${ }^{41}$

¿Cuándo corresponderá a los tribunales peruanos apelar al Artículo VI de la Convención de Nueva York? Si bien hemos afirmado que la facultad es discrecional, ${ }^{42}$ entendemos que solo deberá disponerse la suspensión,

consequence that the arbitral award must be considered as not binding. Otherwise the award would have to be confirmed by a court in the country of origin, "a reintroduction of the doubleexequatur" which the New York Convention clearly had eliminated".

39 Albert Jan van den Berg, "New York Convention of 1958: Consolidated Commentary, Cases reported in Volumes XIII(1988)-XIV(1989)», op. cit., pp. 597-598. Explica el autor, que las cortes de Gran Caimán y Suecia han interpretado correctamente que no basta probar que en aplicación de la ley del lugar en que o conforme a cuya ley se dictó el laudo arbitral, se ha suspendido legalmente su ejecución, sino que hay que demostrar que, efectivamente, la suspensión ha sido dictada por la autoridad competente.

40 Fertilizer Corporation of India vs IDI Management Inc. (Corte de Primera Instancia Federal de los Estados Unidos de América): "Nevertheless, in order to avoid the possibility of an inconsistent result, this Court has determined to adjourn its decision on enforcement of the Nitrophosphate Award until the Indian courts decide with finality whether the award is correct under Indian law. FIC, of course, may apply to this Court for suitable security as provided by Article VI». En ese mismo sentido se pronunció la Corte de Apelaciones de Paris en 1981, en los seguidos por Société Norsolor vs Société Pabalk Tikaret Ltd. SirketzParís. Ver: Michael Tupman, "Staying Enforcement of Arbitral Awards under the New York Convention" op. cit., pp. 215-217.

41 Gary B. Born, "International Commercial Arbitration in the United States", op. cit., p. 496. "[...] many U.S. courts [...] have granted Article VI stays. Caribbean Trading and Fidelity Corp. V. Nigerian National Petroleum Corp., 1990 U.S. Dist. Lexis 17198 (s.D.N.Y. Dec. 18 1990) (staying enforcement proceedings, but requiring security); Spier v. Calzaturificio Tecnica SpA, 663 F.Supp. 871, 874 (S.D.N.Y. 1987) (staying enforcement proceedings, but requiring security);... Hugo Marom Aviation Consultants, Ltd. v. Recon/Optical, Inc., 1991 U.S. Dist. Lexis 8877 (E.D. Ill. May 20, 1991) (refusing to confirm award made in Israel because applications were pending in Israeli courts to vacate and confirm award)".

42 Diversas legislaciones arbitrales han recreado el artículo VI de la Convención de Nueva York, insistiendo en la facultad discrecional del juez. Así, por ejemplo, el Artículo 103(5) del Arbitration Act de Inglaterra de 1996, señala que: "Where an application for the 
cuando a criterio del juez ${ }^{43}$ el proceso seguido ante los tribunales del país de origen pueda derivar en una más que probable anulación del laudo arbitral. ${ }^{44}$

Entendemos que este debe ser el estándard de análisis, a fin de no incumplir con la finalidad última de la Convención de Nueva York, cual es la de posibilitar una rápida y segura ejecución de los laudos arbitrales extranjeros.

setting aside or suspension of the award has been made to such a competent authority [...] the court before which the award is sought to be relied upon may, if it considers it proper, adjourn the decision on the recognition or enforcement of the award.

It may also on the application of the party claiming recognition and enforcement of the award order the other party to give suitable security".

En el mismo sentido se pronuncia el Artículo $4^{\circ}$ de la Regulations for the Execution of the New York Convention de Israel de 1978: "When an application to set aside an award or to suspend it has been brought before the competent authority of the place in which it was made or according to the law of which it was made, the court may postpone the proceedings to another date and, upon the request of the party seeking to confirm the award, it may also order the other party to provide an appropriate security".

Encontramos el mismo contenido en el Artículo $1463^{\circ}$ del Código de Comercio Reformado de México de 1993 y en el Artículo 48(3) del Arbitration and Conciliation Act de la India de 1995.

43 Pieter Sanders, "A Twenty Years' Review of the Convention on the Recognition and Enforcement of Foreign Arbitral Awards", op. cit., p. 273. "Commencing an action to set aside an award in the country where the award was made may nevertheless have some influence on the enforcement of the award abroad. If an application to set aside an award has been made in the award's "home country", the enforcement judge may, if he considers it proper, postpone his decision on enforcement in order to protect the losing party. At the same time, the judge may order that suitable security be given by the party against whom enforcement is sought in order to protect the winning party".

$44 \mathrm{Tal}$ vez el más claro ejemplo de este requisito, lo podemos hallar en el Artículo 1066०(2) de la Ley de Arbitraje de Holanda de 1986, que dispone que: " 2 . [. . J the court [...] may, if there are grounds, at the request of the most appropriate party, suspend the enforcement until a final decision shall have been rendered with respect to the claim for setting aside». De manera similar se ha pronunciado una corte norteamericana, en los seguidos por Spier Calzaturifio v. Tecnica S.p.A. (633 F.Supp. 871,874-976 S.D.N.Y. 1987): "The Court in which enforcement of a foreign arbitral award is sought should not countenance manifestly frivolous attacks upon the award in the country where it was made. I would deny Art.VI adjournment of the enforcement proceedings here only if I were satisfied that Tecnica's litigation position in Italy was transparently frivolous". 


\subsection{Efecto de la anulación o suspensión según la Convención de Nueva York}

Según Berg si un laudo arbitral ha sido anulado o suspendido por la autoridad competente del país en que o conforme cuya ley se dictó el laudo arbitral, ningún otro Estado podrá reconocer y ejecutar dicho laudo al amparo de la Convención de Nueva York. ${ }^{45}$ En otras palabras, según su autorizada opinión, la anulación o suspensión tendrá efectos erga omnes. ${ }^{46}$

Sin embargo, autores de la talla de William Park, ${ }^{47}$ Jan Paulsson, ${ }^{48}$ Gary Born, ${ }^{49}$ Roy Goode ${ }^{50}$ y Hans Smit, ${ }^{51}$ entre otros, opinan que la

45 Albert Jan van den Berg, «New York Convention of 1958: Consolidated Commentary, Cases reported in Volumes XIII(1988)-XIV(1989)", op. cit., p. 595. "The setting aside of an award has extra-territorial effect as it precludes enforcement in the other Contracting States by virtue of ground e of Art. V(1) of the Convention".

46 Comisión de las Naciones Unidas para el Derecho Mercantil Internacional, «Ley Modelo de la CNUDMI sobre Arbitraje Comercial Internacional", nota de la Secretaria (A) CN.9/309), Anuario, 1988, Vol. XIX, pp. 130-131. "[...] la anulación de un laudo en el país en que haya sido dictado impide su ejecución en todos los demás países, conforme al inciso e) del párrafo 1) del artículo $V$ de la Convención de Nueva York y al apartado v) del inciso a) del párrafo 1) del artículo $36^{\circ}$ de la Ley Modelon.

47 William W. Park, "Arbitration of International Contract Disputes», en: The Business Lawyer, Vol. 39, American Bar Association (ABA), 1984, p. 1790. "The Convention permits, but does not require, refusal of recognition to awards annulled where rendered. Despite the permissive, rather than mandatory nature of the provision, courts do not in practice enforce foreign awards set aside in their country of origin".

48 Jan Paulsson, "Delocalization of International Commercial Arbitration: When and Why it matters", en: International and Comparative Law Quarterly, 1983, Vol. 32, p. 60. "In Berardiv. Clair, the award rendered in Geneva was refused recognition by the French court on the grounds that it had been set aside in Geneva. In Geneva, an award may be set aside if the judge decides that the arbitrator's decision was "arbitrary». This is in fact what happened. [...]

1. Whilst it is true that the court behaved as if it had no option but to refuse to enforce the award under the terms of the New York Convention, this simply means that the court erred. Its error may be traced to a specific sentence: the court affirmed that Article $V(1)(e)$ of the New York Convention on the Recognition and Enforcement of Foreign Arbitral Awards provides that la reconnaissance et l'exécution d'une sentence arbitrale doit etre refusée' upon proof that the award has been set aside in the country where it was rendered. The Convention does not say this. The refusal is discretionary".

49 Gary B. Born, "International Commercial Arbitration in the United States", op. cit., p. 649. "[...] the Convention facilitates the recognition of foreign arbitral awards and does nothing to prevent nations from recognizing awards even if they are not obliged to and even if 
Convención de Nueva York permite, mas no obliga, a aplicar esta causal cuando el laudo ha sido anulado en el lugar de origen.

Estas dos posiciones encontradas parecerían sustentarse en una diferente interpretación del texto de la Convención de Nueva York. Así, mientras Berg entiende que la Convención obliga a no reconocer un laudo arbitral anulado en el lugar de origen (shall), Park, Paulsson, Born, Goode y Smit consideran que el tratado es permisivo (may).

Es más, Reisman ${ }^{52}$ explica que este problema de interpretación se presenta simplemente porque en el texto en inglés de la Convención se utiliza la palabra may (podrá), mientras que en los textos en castellano y en francés (igualmente válidos), existiría la obligación de aplicar esta causal..$^{53}$

other countries choose not to. Note, among other things, that Article V's exceptions permit, but do not require, non-recognition".

50 Roy Goode, "The Role of the Lex Loci Arbitri in International Commercial Arbitration", en: Arbitration International, 2001, Vol. 17, No 1, p. 22. "It is clear that Article Vis mandatory only in precluding refusal of enforcement on grounds other than those set out in it. Proof of the existence of one of those grounds entitles the courts of a Convention state to refuse recognition and enforcement but does not oblige them to do so. Refusal is discretionary".

51 Hans Smit, "Proper choice of law and the Lex Mercatoria Arbitralis", en: Lex Mercatoria and Arbitration, Thomas E. Carbonneau (ed.), Juris Publishing Inc., 1998, p. 105. «The New York Convention on the Recognition and Enforcement of Foreign Arbitral Awards [...] provides only that a court in a Convention state "may" refuse to enforce an award if it "has been set aside» or suspended by a competent authority of the country in which, or under the law of which, the award was made. Accordingly, the Convention does not [...] impose an obligation to refuse enforcement; on the contrary, it leaves the court in the second state free to grant recognition".

52 W. Michael Reisman, Systems of Control in International Adjudication \& Arbitration-Breakdown and Repair-, Duke University Press, 1992, p. 115. «Because of the language in the English text of the convention, the control system has appeared to some to be optional rather than imperative: 'recognition and enforcement of the award may be refused' but may be refused "only" if there is proof of a defect, as detailed by the convention. The French text of the convention, which is equally authentic, suggests that the control system is mandatory. The Spanish text is even more clearly mandatory".

53 Sin embargo, Gary H. Sampliner, "Enforcement of Nullified Foreign Arbitral Awards -Chromalloy Revisited", en: Journal of International Arbitration, 1997, Vol. 14, No 3, p. 150, opina de manera diferente: "A number of commentators have pointed to the French language version of Article V (which under Article XVI of the Convention is deemed to be as equally authentic as the English version), and note that in French Article V provides that "enforcement will not be refused [...] unless [...]". This phrase, they note, suggests the inference that enforcement must be refused if one of the Article $V$ defenses applies... Yet this version can be read to have the same meaning as the English language version-i.e. that courts must enforce 
Sin embargo, nosotros entendemos que la discusión, si bien tiene como excusa la aparente falta de uniformidad entre los textos oficiales de la Convención, en el fondo esconde un problema mayor.

En efecto, si leemos con cuidado la cita de Paulsson acerca del caso Berardi vs Clair, ${ }^{54}$ verificaremos que el autor está preocupado porque el fallo arbitral dictado en Génova había sido anulado en base a una causal doméstica bastante particular (arbitrary), ajena a las causales de la Convención de Nueva York.

Como explica Park, ${ }^{55}$ la Convención de Nueva York solo establece las causales que serán de aplicación para que no proceda el reconocimiento y la ejecución de un laudo arbitral extranjero, pero deja en total libertad a las leyes domésticas de cada Estado para determinar las causales de anulación.

Y esta libertad tiene un claro efecto sobre la Convención de Nueva York: si la causal bajo estudio "debe" ser siempre aplicada, entonces los Estados miembros de dicho tratado se verán en la obligación de no reconocer y ejecutar laudos arbitrales anulados por el poder judicial del lugar del arbitraje, muchas veces en base a causales exóticas o, inclusive, arbitrarias, causando con ello graves perjuicios al arbitraje internacional. ${ }^{56}$

foreign arbitral awards if the Article $V$ defenses have not been proven, but that they may choose not to enforce such award is an Article V defense applies". De manera similar se pronuncia Jan Paulsson, "Enforcing Arbitral Awards notwithstanding a local standard annulment (LSA)", en: The ICC International Court of Arbitration Bulletin, 1998, Vol. 9, No 1, p. 17. "I do not, however, agree that the French text excludes discretion under Article V. Moreover, the three other texts of the Convention (Chinese, Spanish, and Russian) are congruent with the English, and principles applicable to plurilingual treaties militate against one exception francaise".

54 Ver supra cita No 48.

55 William W. Park, "Finality and Fairness in Tax Arbitration", en: Journal of International Arbitration, Vol. 11, No 2, 1994, pp. 25-26. "Under the New York Convention, for example, annulment of awards is left to the national law of the arbitral situs. If an award rendered in Paris is annulled by a French court, the Convention permits courts in New York to refuse recognition of the award. However, the grounds on which the award might be set aside would be determined by French arbitration law, not the New York Convention".

56 William W. Park, "Duty and discretion in International Arbitration", en: American Journal of International Law, The American Society of International Law, Vol. 93, No 4, 1999, p. 805. «Unconditional respect for all foreign annulments will hardly promote efficient arbitration, since an award might be annulled in bad faith or in violation of fundamental notions of justice". William W. Park, "Judicial Controls in the Arbitral Process", en: Arbitration International, Vol. 5, No 3, 1989, p. 258. "The Convention makes no distinction among the various grounds on which the award was set aside, whether for a matter as serious as arbitrator corruption or as parochial as failure to state reasons". 
Sin embargo, Berg ${ }^{57}$ insiste en que no es posible reconocer y ejecutar un laudo anulado en el lugar del arbitraje, por cuanto: "The disregard of annulment of the award... involves basic legal concepts. When an award has been annulled in the country of origin, it has become non-existent in that country. The fact that the award has been annulled implies that the award was legally rooted in the arbitration law of the country of origin. How then is it possible that courts in another country can consider the same award as still valid? Perhaps some theories of legal philosophy may provide an answer to this question, but for a legal practitioner this phenomenon is inexplicable. It seems that only an international treaty can give a special legal status to an award notwithstanding its annulment in the country of origin".

A esta importante opinión, hay que agregar la del profesor Pieter Sanders, ${ }^{58}$ que entiende que durante la redacción de la Convención de Nueva York siempre quedó claro para todas las delegaciones involucradas, que anulado el laudo en el lugar del arbitraje, este tenía un efecto erga omnes; posición que, en la práctica, es compartida por la gran mayoría de fallos judiciales y trabajos académicos. ${ }^{59}$

¿Por qué no se ha seguido la postura defendida por Park, Paulsson y otros? ¿Es que acaso la comunidad internacional no desea contar con un sistema ágil de reconocimiento y ejecución de laudos arbitrales?

57 Citado por Gary H. Sampliner, «Enforcement of Nullified Foreign Arbitral Awards Chromalloy Revisited", op. cit., pp. 145-146.

58 Ibidem, pp. 146-149: "[...] the history of the Convention shows that in every draft presented, the annulment of an award in the country where it was made was a ground for refusal of enforcement in other countries, without any express exceptions. [...]

The contemporaneous writings of one of the Convention's key participants, Professor Pieter Sanders, also support the conclusion that the Convention drafters assumed that if an arbitral award was nullified by the courts of the country of origin, it would be improper to enforce such an award under any circumstances. Professor Sanders wrote, shortly after the Convention was signed, that once an award has been set aside by the courts of the country of origin: "[...] the Courts [of the enforcing countries] will... refuse the enforcement as there does no longer exist an arbitral award and enforcing a non-existing arbitral award would be an impossibility or even go against the public policy of the country of enforcement" ".

$59 \mathrm{El}$ propio William W. Park, "National Law and Commercial Justice: Safeguarding procedural integrity in International Arbitration», en: Tulane Law Review, Vol. 63, No 3, 1989, p. 658, reconoce que: "[...] an award annulled under the law of the country in which it was rendered will usually be refused recognition and enforcement abroad. Enforcement of an annulled award is rare in practice and is mandated by treaty only if the parties are covered by 
Tal vez la respuesta la encontremos nuevamente en palabras de Berg: ${ }^{60}$ "A losing party must be afforded the right to have the validity of the award finally adjudicated in one jurisdiction. If that were not the case, in the event of a questionable award, a losing party could be pursued by a claimant with enforcement actions from country to country until a court is found, if any, which grants the enforcement. A claimant would obviously refrain from doing this if the award has been set aside in the country of origin and this is a ground for refusal of enforcement in other Contracting States.

En otras palabras, si la comunidad internacional no reconoce erga omnes la anulación de un laudo arbitral, se perjudicaría manifiestamente a la parte que ganó la anulación, ya que la otra parte la podría llevar a litigar a cuanto poder judicial quisiera, con la finalidad de intentar que en algún lugar se ejecute el laudo arbitral anulado. ${ }^{61}$

Este efecto pernicioso es el que ha llevado inclusive a los propios impulsores de la posición contraria al efecto erga omnes, a considerar que es necesario encontrar un balance entre las espectativas de las partes y de los Estados que forman parte de la Convención de Nueva York. ${ }^{62}$

the 1961 European Convention". En el mismo sentido se pronuncia Gary B. Born, "International Commercial Arbitration in the United States", op. cit., p. 463. "As a practical matter, if an award is vacated in the arbitral forum, it is unlikely that it will be recognized and enforced elsewhere. Nevertheless, although it occurs infrequently, some commentators take the view that, even if an arbitral award is vacated in the situs, it can still be enforced in other states".

60 Citado por Lawrence W. Newman \& Michael Burrows, "Setting Aside Arbitral Awards under the New York Convention", en: The New York Law Journal, November 18, 1997 , p. 5.

61 Este problema también es identificado por William W. Park, "Duty and discretion in International Arbitration", op, cit., p. 805, cuando reconoce que si no hay alguna deferencia hacia la anulación del laudo arbitral en el lugar del arbitraje, "[...] victims of tainted arbitrations must prove de novo the award's defects in every jurisdiction where they either have assets or sep to rely on subsequent awards". En el mismo sentido, Pippa Read, "Delocalization of International Commercial Arbitration: Its relevance in the New Millennium", en: American Review of International Arbitration, Vol. 10, 1999, pp. 186-187. "This proposal has been criticized, however, as it would not adequately address those situations where a fundamental breach of procedural fairness did arise. If, for example, an arbitrator was clearly biased and an award was issued, the practical consequences of completely delocalizing the award would mean that the losing party would have to challenge that award in each of the jurisdictions where it might be enforced against that party's property. This would be a cost and time-consuming exercise which would run counter to the aim for finality in international commercial arbitration".

62 También resultan más que pertinentes las palabras de Gary H. Sampliner, "Enforcement of Nullified Foreign Arbitral Awards -Chromalloy Revisited», op. cit., p. 157: «I 
En efecto, Park ${ }^{63}$ considera que un laudo arbitral anulado en el lugar del arbitraje debería ser reconocido solo en dos circunstancias: cuando se presuma que el poder judicial del lugar del arbitraje es corrupto o no es neutral; $y$, cuando el laudo arbitral haya sido anulado por causales tan particulares (por no decir, exóticas o arbitrarias), que el no reconocimiento del laudo implique atentar contra la eficacia del arbitraje internacional. ${ }^{64}$

would submit, however, that the unilateral disregard of foreign annulment decisions per se, by the legislature or courts of France, the United States, or any other country, would be harmful, on balance, to the goals of international commercial arbitration. First, there is a measure of disrespect for the courts of the rendering countries implicit in the automatic disregard of their annulment decisions which runs contrary to notions of comity that prevail, to one degree or another, in most of the world. Countries which have chosen to enact laws permitting arbitration provided that annulment of awards is permitted on particular national grounds will not be unamoured with the international arbitral process if other countries enact laws which says in effect, that the policies and court decisions of the country decisions of the country of arbitration will be given no effect whatsoever".

63 William W. Park, "Arbitration of International Contract Disputes", op. cit., pp. 1794-1795. "Enforcement of an award annulled in its country of origin might be appropriate in two cases. The first presumes that the local judiciary is corrupt or biased. For example, a judge in a country lacking a tradition of judicial independence might set aside an award rendered against his own government merely to please the bureaucracy. Secondly postannulment recognition might be justified where the award was set aside for reasons so peculiar to the local law of the place of the proceedings that nonrecognition would defeat an efficient international arbitral process. For example, the local law of the place of the proceedings might provide that all arbitrators must sign the award".

64 Gary H. Sampliner, "Enforcement of Nullified Foreign Arbitral Awards-Chromalloy Revisited", op. cit., p. 162: "A balance can be struck between these interest by permitting enforcement of nullified foreign awards when the enforcing courts find the nullification decisions to be arbitrary or clearly erroneous, in addition to any decisions that are proven to have stemmed from corruption, bias, or which violate the public policy of the enforcing country. By implementing a standard of this sort, enforcing countries would give deference to the decisions of the courts of the country of origin, unless they cannot discern a viable basis for the foreign courts' decision, while at the same time honouring the choice of the contracting parties to resolve their disputes by final and binding arbitration». Gary H. Sampliner, "Enforcement of Foreign Arbitral Awards after Annulment in their Country of Origin", en: Mealey's International Arbitration Report, 1996, Vol. 11, No 9, p. 591. "Over the years, a number of writers have postulated various circumstances under which the courts of enforcing countries could be justified in enforcing an arbitral award notwithstanding its having been set aside in the country of origin. For example, some commentators have suggested that enforcement might be permitted where the setting aside decision is found to be "clearly wrong, or improperly reache", or where the court in the country of origin is "manifestly corrupt, biased, or arbitrary". 
Sin embargo, el principal problema con este argumento es: ¿Y quién va a definir cuándo un poder judicial es corrupto o no es neutral? ¿Quién va a determinar cuándo una causal es lo suficientemente «exótica o arbitraria», como para justificar el reconocimiento y la ejecución de un laudo arbitral anulado en el lugar del arbitraje?

Si bien comprendemos la legítima preocupación de connotados expertos en arbitraje como los citados, en el sentido de que hay que buscar un sistema de reconocimiento y ejecución de laudos arbitrales que sea seguro y predecible, lo cierto es que intentar hacerlo forzando el contenido del artículo $\mathrm{V}(1)$ (e) de la Convención de Nueva York, es en nuestra opinión inapropiado y muy peligroso. ${ }^{65}$

En todo caso, conviene aclarar que esta postura ha perdido una batalla, pero no la guerra. En efecto, Sampliner ${ }^{66}$ hace referencia de un caso arbitral que debemos citar: Se trata de un arbitraje con sede en El Cairo, entre una empresa norteamericana (Chromalloy Aeroservices) y la República Árabe de Egipto (conocido como el Chromalloy Case), en el que se laudó a favor de la empresa privada, pero luego el poder judicial egipcio lo anuló en base a una causal particular de la legislación arbitral egipcia.

Sin embargo, aún cuando el laudo había sido anulado por el poder judicial del lugar del arbitraje, la empresa norteamericana solicitó su reconocimiento y ejecución ante su propio poder judicial.

La corte norteamericana, y, luego, la francesa, aceptaron reconocer y ejecutar el laudo arbitral anulado en Egipto, ${ }^{67}$ aplicando no el artículo V(1)(e), sino el artículo VII de la Convención de Nueva York. ${ }^{68}$

65 Opinión que creemos es compartida por la generalidad de la doctrina y fallos judiciales.

66 Gary H. Sampliner, «Enforcement of Nullified Foreign Arbitral Awards-Chromalloy Revisited", op. cit., p. 139 y ss.

67 Sin embargo, subsecuentes fallos del poder judicial norteamericano no han seguido esta postura, como lo demuestran los casos Baker Marine Ltd. vs. Chevron Ltd. (Segundo Circuito Federal, 1999) y Spier vs. Calzaturificio Tecnica, S.p.A. (71 F. Supp. 2d. 279, S.D.N.Y., 1999), en los que las cortes se negaron a aplicar la legislación arbitral norteamericana en base al artículo VII de la Convención de Nueva York, a efectos de reconocer y ejecutar sendos laudos arbitrales anulados en Nigeria e Italia, respectivamente, lugares en los que se desarrollaron los arbitrajes. Sobre el particular, leer a: William W. Park, "Duty and discretion in International Arbitration», op. cit., p. 807; y, Pippa Read, "Delocalization of International Commercial Arbitration: Its relevance in the New Millennium», op. cit., p. 196.

68 Gary H. Sampliner, "Enforcement of Nullified Foreign Arbitral Awards-Chromalloy Revisited", op. cit., p. 142. "The Court's decision mentioned its discretionary power to enforce 
Sobre este particular, debemos mencionar que el artículo VII de la Convención de Nueva York ${ }^{69}$ regula lo que en doctrina se denomina el principio de "eficacia máxima" ${ }^{70}$ mediante el cual si las normas de otro tratado o las disposiciones nacionales son más favorables al reconocimiento y la ejecución que las de ese tratado, primarán las primeras. ${ }^{71}$

En base a este principio, si bien el gobierno de Egipto alegó que de conformidad con el artículo V(1)(e) de la Convención de Nueva York y el artículo

the award under Article V(1)(e), but was based primarily on Article VII of the Convention, which permits the enforcement of foreign awards if enforcement is permitted under the domestic law of the enforcing country. Six months later, the Court of Appeal of Paris upheld Article VII and French law similar to that which had been followed in previous French enforcement cases».

69 Artículo VII(1) de la Convención de Nueva York: «Las disposiciones de la presente Convención no afectarán la validez de los acuerdos multilaterales o bilaterales relativos al reconocimiento y la ejecución de las sentencias arbitrales concertados por los Estados Contratantes ni privarán a ninguna de las partes interesadas de cualquier derecho que pudiera tener a hacer valer una sentencia arbitral en la forma y medida admitidas por la legislación o los tratados del país donde dicha sentencia se invoque".

70 José Carlos Fernández Rozas, "La primacía de los Tratados Internacionales en el Exequatur de sentencias arbitrales extranjeras", en: Revista de la Corte Española de Arbitraje, Vol. VII, Editorial Civitas, Madrid, 1991, p. 25. «Lo dispuesto en este precepto se enmarca dentro de la regla de la "eficacia máxima", en virtud de la cual en caso de discrepancia entre lo dispuesto en distintos Convenios, la preferencia corresponde a aquel que posea unos presupuestos de reconocimiento y de ejecución más liberales o a aquel que incluya un procedimiento más simplificado". Albert Jan van den Berg, "New York Convention of 1958: Consolidated Commentary, Cases reported in Volumes XIII(1988)-XIV(1989)", op. cit., pp. 609-610. "When interpreting this provision, the Swiss Federal Supreme Court applied the rule of conflict of treaties called the rule of maximum effectiveness [regle d' efficacité maximale]. Under this rule, in case of discrepancies between provisions in international conventions regarding the recognition and enforcement or arbitral awards, preference will be given to the provision allowing or making easier such recognition and enforcement, either because of more liberal substantive conditions or because of a simpler procedure".

71 La propia LGA recoge este principio en la parte final del artículo $128^{\circ}$ y en el primer párrafo del artículo $129^{\circ}$, al disponer que la norma aplicable será aquella más favorable a la parte que pida el reconocimiento y ejecución del laudo arbitral. El mismo principio se encuentra incorporado, por ejemplo, en el Artículo $45^{\circ}(2)$ de la Ley de Arbitraje de Guatemala de 1995: «En el caso de que más de un tratado internacional sea aplicable, salvo acuerdo en contrario entre las partes, se aplicará el más favorable a la parte que solicite el reconocimiento y ejecución de un convenio y laudo arbitral"; y, en el Artículo $80^{\circ}$ (II) de la Ley de Arbitraje y Conciliación No 1770 de Bolivia de 1997: «Salvo acuerdo en contrario y para el caso de existir más de un instrumento internacional aplicable, se optará por el tratado o convención más favorable a la parte que solicite el reconocimiento y ejecución del laudo arbitral». 
correspondiente de la ley norteamericana que incorporó dicho tratado, el laudo anulado en Egipto no debía ser reconocido y ejecutado, la corte norteamericana consideró que en base al artículo VII de la Convención de Nueva York, podían aplicarse las disposiciones locales sobre la materia (Capítulo 1 de la Federal Arbitration $A c t$ ) y, por tanto, cabía reconocer y ejecutar el laudo arbitral..$^{72}$ Idéntica fue la postura asumida por la corte francesa. ${ }^{73}$

Este no es el único caso existente. Gaillard ${ }^{74}$ por ejemplo identifica otro resuelto por la Corte de Casaciones de Francia el 10 de junio de 1997, en los seguidos por Hilmarton Ltd. v. Omnium de traitement et de valorisation (OTV).

Se trató de un contrato de consultoría para el gobierno de Argelia suscrito en 1980, respecto del cual se generó una discusión acerca del pago de honorarios. Al existir una cláusula arbitral, las partes arbitraron en Génova, bajo las reglas arbitrales de la Cámara de Comercio Internacional (CCI). Dictado el laudo, se inició el procedimiento de anulación en Suiza (lugar del arbitraje), que culminó con la anulación del fallo en abril de 1990. Sin embargo, el laudo fue reconocido en Francia por la Corte de Apelaciones de París en diciembre de 1991 y confirmado meses después por la Corte de Casaciones. ${ }^{75}$

72 Gary H. Sampliner, "Enforcement of Nullified Foreign Arbitral Awards-Chromalloy Revisited", op. cit., p. 152: "Egypt argued that enforcement of a nullified foreign award pursuant to Chapter 1 of the FAA would violate this statute, because it would conflict with 9 U.S.C207, which purportedly requires a refusal to enforce a nullified foreign award. The Court rejected this argument, appropriately in my view, because the terms of the Convention ratified by the United States include Article VII, which permit foreign awards to be enforced notwithstanding any Article $V$ defense, if the domestic law of an enforcing country permits enforcement of that award".

73 Jan Paulsson, «Enforcing Arbitral Awards notwithstanding a local standard annulment (LSA)", op. cit., p. 16. "Chromalloy achieved similar sucess in France [...] The Paris Court [...] concluded that the French courts were [...] required to apply French law to enforce the award; French law is more favourable than the Convention inasmuch as it does not recognize the annulment of an award abroad as a ground to refuse to enforce its.

74 Emmanuel Gaillard, "Enforcement of a Nullified Foreign Award», en: The New York Law Journal, Octubre, 2, 1997, pp. 1-4.

75 William W. Park, "Duty and discretion in International Arbitration», op. cit., pp. 806807. Como explica el autor, el caso fue aún más complejo, por cuanto al haber sido anulado el primer laudo en Suiza, se inició en ese país un segundo proceso arbitral que culminó a favor de la otra parte. Presentado este segundo laudo para reconocimiento y ejecución en Francia, fue en un primer momento reconocido, aunque finalmente fue desestimado por la Corte de Casaciones francesa en aplicación del principio de cosa juzgada. 
Delaume por su parte, hace referencia al caso entre Société Pabalk Ticaret Ltd. Sirkati v. Société Norsolor (1984), seguido también ante el poder judicial francés. Se trató de un laudo arbitral dictado en Austria, que fue reconocido y ejecutado en primera instancia en Francia, cuando se encontraba en trámite el recurso de anulación en el lugar del arbitraje. El laudo fue finalmente anulado en Austria, bajo la causal de que fue dictado en equidad, cuando correspondía hacerlo en derecho, lo que motivó que la Corte de Apelaciones de París decidiera no reconocer y ejecutar el laudo arbitral, de conformidad con el artículo V(1)(e) de la Convención de Nueva York. ${ }^{76}$

Sin embargo, la Corte de Casaciones consideró aplicable la legislación francesa al amparo del artículo VII de la Convención de Nueva York, ${ }^{77}$ por lo que al ser su Código Procesal Civil más favorable al reconocimiento y la ejecución de laudos arbitrales ${ }^{78}$ reconoció y ejecutó el laudo arbitral, ${ }^{79}$ aun cuando había sido anulado en Viena. ${ }^{80}$

76 Georges Delaume, "SEEE v. Yugoslavia: Epitaph or Interlude?», en: Journal of International Arbitration, 1987, Vol. 4, No 3, pp. 34-35. "[...] another decision of the Cour de Cassation in Société Pabalk Ticaret Ltd. Sirkati v. Societé Norsolor, supplies as answer. This case concerned the recognition in France of an ICC award rendered in Austria, which had been the subject of an annulment proceeding in the Austrian courts. Recognition was initially granted, but following a decision of the Court of Appeal of Vienna invalidating the award, the Court of Appeal of Paris held that the order granting recognition should be retracted. The Court relied on Article $V$ (1)(e) of the New York Convention according to which recognition and enforcement of an award may be refused if it has been "set aside" in the country in which it was made".

77 Ibidem, p. 35. "This decision was quashed by the Cour of Cassation. The judgement of the Cour is based on two considerations, one of which relates to the New York Convention and the other to French law.

Referring to Article VII(1) of the New York Convention, the Cour holds that, under this provision, a French recognizing court may not refuse recognition when it is authorized to grant it under French law».

78 En efecto, el artículo $1502^{\circ}$ del Código Procesal Civil francés, solo reconoce las siguientes causales:

"l. If the arbitrator decided in the absence of an arbitration agreement or on the basis of a void or expired agreement;

2. If the arbitral tribunal was irregularly composed or the sole arbitrator irregularly appointed;

3. If the arbitrator decided in a manner incompatible with the mission conferred upon him;

4. If due process was not respected;

5. If recognition or enforcement would be contrary to international public policy".

79 Georges Delaume, «SEEE v. Yugoslavia: Epitaph or Interlude?», op. cit., p. 35. "In fact, since the provisions of the New Code of Civil Procedure are more favourable to the recognition of "international awards", than those of the Convention regarding the recognition of «foreign" awards', the decision means that French law will prevail over the Convention". 
El argumento principal para la inteligente utilización del artículo VII de la Convención de Nueva York conjuntamente con la legislación doméstica más favorable al reconocimiento y ejecución de un laudo arbitral, la da Paulsson: ${ }^{81}$ "The purpose of the New York Convention was simply to make it easier to enforce foreign awards by establishing a minimum standard for obligating enforcement, not to establish a comprehensive and unitary regime. To the extent that past or future rules allowed enforcement without the Convention, the latter was not intended to intrude; Article VII makes this clear, providing that national rules or indeed other treaties shall be given preference if they are more favourable to enforcement».

En nuestra opinión, aún cuando consideramos que resulta interesante este proceder, nos encontramos nuevamente con un grave problema: Solo es aplicable en aquellos Estados cuya ley arbitral es más favorable que la Convención de Nueva York, lo que implica que solo es útil en Holanda y Francia, ${ }^{82}$ y, al parecer, en los Estados Unidos de América y en algunos otros pocos Estados. ${ }^{83}$

En cambio no es aplicable, por ejemplo, en el Perú, ya que las causales dispuestas en la LGA para no reconocer y ejecutar un laudo arbitral ex-

80 Jan Paulsson, «Enforcing Arbitral Awards notwithstanding a local standard annulment (LSA)", op. cit., pp. 15-16. Este importante autor identifica, además, los siguientes casos: "SONATRACH v. Ford, Bacon and Davis Inc [...] (ICC award rendered in Algiers in favour of U.S. party declared enforceable in Belgium notwithstanding its having been "overruled». (infirmee) by the Court of Appeal of Algiers; New York Convention held inapplicable because Algeria acceded to it after award had been rendered, and no grounds for refusal of enforcement under Belgian law had been shown); Ministry of Public Works of Tunisia v. Societe Bec Fréres [...] (award enforced in France notwithstanding a Tunisian court judgment declaring the arbitration clause to be null and void) [...]".

81 Ibidem, p. 18.

82 Georges R. Delaume, "Reflections on the Effectiveness of International Arbitral Awards", en: Journal of International Arbitration, Vol. 12, No 1, 1995, p. 13. "However, it should be borne in mind that the Convention (Article VII(1)) does not deprive a party from seeking recognition of an award on the basis of domestic rules when these may be more favourable to recognition than the provisions of the Convention. This is an option which has been acknowledged in such countries as the Netherlands, Germany, and France».

Sin embargo, entendemos que esta ya no es más la postura alemana, en base al artículo $1061^{\circ}(3)$ del nuevo German Arbitration Act: "If the award is set aside abroad after having been declared enforceable, application for setting aside the declaration of enforceability may be maden.

83 Jan Paulsson, "Enforcing Arbitral Awards notwithstanding a local standard annulment (LSA», op. cit., p. 20. "The same is true for any other country where the law has a narrower definition of defective awards than that of Article Vof the Convention [...]". 
tranjero (artículo $129^{\circ}$ ), son las mismas que las establecidas en el artículo $V$ de la Convención de Nueva York, razón por la cual, mientras nuestras normas no sean más "favorables" a las contenidas en el mencionado tratado, será de aplicación la Convención de Nueva York al reconocimiento y ejecución de los laudos arbitrales que provengan del extranjero, en base a la supremacía de los tratados sobre la legislación doméstica que reconoce la propia LGA.

De esta manera, la utilización del artículo VII de la Convención de Nueva York es marginal y muy poco valiosa al momento de intentar resolver, de manera general y uniforme, el problema generado por el artículo $\mathrm{V}(1)(\mathrm{e})$ de dicho tratado, que deja a la decisión de cada Estado miembro la determinación de las causales de anulación de los laudos arbitrales dictados dentro de sus fronteras.

¿Qué hacer entonces? ¿Cómo debería solucionarse este problema en un futuro próximo? Tratemos de contestar estas interrogantes.

En primer lugar, conviene precisar que el problema se reduce a la necesidad de reducir, valga la redundancia, la discrecionalidad de la ley del Estado en que o conforme a cuya ley arbitral se dicta un laudo arbitral, en relación a las causales de anulación de laudos arbitrales, con la finalidad de que no se afecte el reconocimiento y la ejecución de los laudos arbitrales extranjeros.

Identificado el problema, lo que se quiere es que exista, como propone Paulsson ${ }^{84}$ un "Estandard Internacional» en materia de anulación de laudos arbitrales. En otros términos, que existan causales de anulación internacionalmente reconocidas que sean, solo ellas, las que vinculen erga omnes a los demás Estados.

En palabras de Sampliner, dichas causales serían las establecidas en el artículo $\mathrm{V}(1)(\mathrm{a}-\mathrm{d})$ de la Convención de Nueva York. ${ }^{85}$

84 Jan Paulsson, «Enforcing Arbitral Awards notwithstanding a localstandard annulment (LSA)», op. cit., p. 14. "National courts should now be prepared to allow the arbitral process to become truly international, by enforcing awards rendered in other countries on the basis of no other criteria than those which are internationally accepted. To be more specific, I propose that the annulment of an award by the courts in the country where it was rendered should not be a bar to enforcement elsewhere unless the grounds for that annulment were ones that are internationally recognized".

85 Gary H. Sampliner, "Enforcement of Nullified Foreign Arbitral Awards -Chromalloy Revisited", op. cit., p. 162: "Paulsson [...] recommends that courts should honour so-called "International Standard Annulment" decisions-i.e. those decisions which are based on the 
¿Cómo implementar la idea? Creemos que enfrentándola de dos maneras:

La primera, como bien lo explica Read ${ }^{86}$ se viene implementando gracias a que cada vez son más estados los que están modificando sus legislaciones arbitrales (muchas de ellas obsoletas) incorporando disposiciones modernas que cubren las expectativas del arbitraje internacional. En ese proceso, destaca la adopción de leyes arbitrales que siguen muy de cerca la Ley Modelo de UNCITRAL. ${ }^{87}$

Pero, además, creemos que sería necesario un protocolo adicional a la Convención de Nueva York, que siga el camino ya trazado por la Convención Europea sobre Arbitraje Comercial Internacional (Ginebra, 1961), ${ }^{88}$ la que en su artículo IX dispone que la anulación de un laudo en

internationally recognized grounds under Articles $v(1)(a-d)$ of the New York Convention for refusal to enforce foreign arbitral awards, but that they should give no effect to so-called "Local Standard Annulments decisions, i.e. decisions to annul awards based on any other ground of local law».

86 Pippa Read, "Delocalization of International Commercial Arbitration: Its relevance in the New Millennium", op. cit., p. 199. "In practice, many of these undesirable consequences no longer exist, due to the emerging uniformity of national arbitration laws governing international arbitration. Many nations, which in the past displayed these unwanted characteristics, suffered commercially as a result of the decline in international arbitrations conducted within their borders. In response, these nations have amended their national arbitration laws in line with the current needs and expectations of parties to international arbitration. This process has been substantially assisted by the existence of the UNCITRAL Model Law on International Commercial Arbitration".

87 Según la Comisión de las Naciones Unidas para el Derecho Mercantil Internacional (UNCITRAL por sus siglas en inglés), se "han promulgado leyes basadas en la Ley Modelo de la CNUDMI sobre arbitraje comercial internacional en Alemania, Australia, Azerbaiyán, Bahrein, Belarús, Bermudas, Bulgaria, el Canadá, Chipre, Croacia, Egipto, dentro del Reino Unido de Gran Bretaña e Irlanda del Norte: Escocia, la Federación de Rusia, Grecia, Guatemala, Hong Kong (Región administrativa especial de China), Hungría, la India, Irán (República Islámica del), Irlanda, Jordania, Kenya, Lituania, Madagascar, Malta, México, Nigeria, Nueva Zelandia, Omán, el Perú, la República de Corea, Macao (Región administrativa especial de China), Singapur, Sri Lanka, Túnez, Ucrania; dentro de los Estados Unidos de América: California, Connecticur, Illinois, Oregón y Texas; Zambia, y Zimbabwe».

88 Gary B. Born, "International Commercial Arbitration in the United States", op. cit., p. 649. "The 1961 European Convention on International Commercial Arbitration applies to disputes between nationals of different signatories; the European Convention obliges signatory states to enforce arbitral awards, except where they have been vacated for specified reasons. Where an award in a dispute between nationals of signatory states is vacated in a country on a basis not recognized in the European Convention, the obligation to enforce would remain". 
el lugar del arbitraje solo será efectiva erga omnes, si es que se basa en alguna de las causales establecidas en dicho tratado. ${ }^{89}$

89 Gary H. Sampliner, "Enforcement of Nullified Foreign Arbitral Awards-Chromalloy Revisited", op. cit., p. 146. "As Dr. van den Berg notes, the European Convention on International Commercial Arbitration (European Convention of 1961) does expressly permit the enforcement of arbitral awards that have been set aside in other signatory countries for reasons not enumerated therein-e.i. the four internationally recognized standards for refusal to enforce an award set forth in Article v(1)(a-d) of the New York Convention». William W. Park, "Finality and Fairness in Tax Arbitration", op. cit., pp. 25-26. "Under the New York Convention, for example, annulment of awards is left to the national law of the arbitral situs. If an award rendered in Paris is annulled by a French court, the Convention permits courts in New York to refuse recognition of the award. However, the grounds on which the award might be set aside would be determined by French arbitration law, not the New York Convention. In contrast, the 1961 European Convention on International Commercial Arbitration, which complements the New York Convention in disputes among residents of European countries, permits refusal of recognition of an award annulled in another Contracting State only if the annulment was for a Convention-enumerated reason".

El artículo IX de la Convención de Ginebra dispone lo siguiente:

"1. La anulación en uno de los Estados contratantes de un laudo arbitral amparado por el presente Convenio constituirá causa de denegación en lo referente al reconocimiento o ejecución de dicho laudo en otro Estado contratante, solo en el caso de que tal anulación se hubiere llevado a efecto en aquel Estado en el cual o conforme a cuya ley fue pronunciado el fallo arbitral, y ello por una de las siguientes razones:

a) las partes en el acuerdo o compromiso arbitral estaban, con sujeción a la ley a ellas aplicables, afectadas de una incapacidad de obrar, o dicho acuerdo o compromiso no era válido con arreglo a la ley a la cual lo sometieron las partes o, en caso de no haber indicación al respecto, conforme a la ley del país en donde se dictó el laudo; o

b) la parte que pide la anulación del laudo no había sido informada debidamente sobre el nombramiento del árbitro o sobre el desarrollo del procedimiento arbitral, o le había sido imposible, por cualquier otra causa, hacer valer sus alegaciones o recursos; 0

c) el laudo se refiere a una controversia no prevista en el compromiso arbitral o no incluida dentro de lo establecido en la cláusula compromisoria, o contiene decisiones sobre materias que sobrepasen los términos del compromiso arbitral o de la cláusula compromisoria, entendiéndose, empero, que si las resoluciones del laudo que versen sobre cuestiones sometidas al arbitraje puedan ser separadas o disociadas de aquellas otras resoluciones concernientes a materias no sometidas al arbitraje, las primeras podrán no ser anuladas; 0

d) la constitución o composición del tribunal arbitral o el procedimiento arbitral no se ha ajustado al acuerdo o compromiso entre las partes o, no habiendo existido tal acuerdo o compromiso, a lo establecido en el artículo IV del presente Convenio.

2. En las relaciones entre aquellos Estados contratantes que sean al mismo tiempo Partes en el Convenio de Nueva York de 10 de Junio de 1958 sobre Reconocimiento y 
Con una reforma en ambos sentidos como la indicada, entendemos que se logrará, en un futuro próximo, la tan necesaria predictibilidad y uniformidad en el reconocimiento y la ejecución de los laudos arbitrales extranjeros. ${ }^{90}$

Ejecución de Sentencias Arbitrales Extranjeras, el párrafo 1 del presente artículo viene a restringir la aplicación del artículo V, párrafo 1, e) del Convenio de Nueva York únicamente a los casos de anulación expuestos en dicho párrafo 1".

Entre los Estados signatarios de esta Convención exclusivamente aplicable a Estados Europeos, tenemos a: Alemania, Austria, Bélgica, Bielorrusia, Bulgaria, Dinamarca, Eslovaquia, España, Finlandia, Francia, Hungría, Italia, Polonia, República Checa, Rumania, Turquía, Ucrania y Yugoslavia.

90 Pieter Sanders, "A twenty Years' Review of the Convention on the Recognition and Enforcement of Foreign Arbitral Awards", op. cit., p. 276. "The Geneva Convention of 1961 [...] contains a limitation of the grounds for set asides in arbitrations that deal with 'disputes arising from international trade [...].

This example might be followed when modification of the New York Convention is considered. The New York Convention could be modified to provide that the grounds for set asides in the country where awards are made should be limited to those mentioned as grounds for refusal under said paragraph a-d in disputes arising out of international trade». 